\title{
Muslim Networks and Transnational Communities in and across Europe
}

Stefano Allievi and Jorgen Nielsen, eds.

Leiden, The Netherlands: E. J. Brill, 2003. 332 pages.

Through networks and media, European Muslims finally emerged as social and public actors in both European societies and the context of the broader ummah. This is the core subject of the book, an edited collection that examines the networks and ways in which Muslims engage in the public sphere. The discussion is supported with various case studies.

According to two of the contributors, Mark Le Vine and Peter Mandaville, European Islam can develop alternative Muslim views that affect the native homelands of European Muslims and also contribute to the dynamic of self-perception and self-interpretation of Islam. European Muslims animate religious debates and contribute to developing a critical, pluralistic, and less conservative view of Islam. According to Mandaville, differences (viewed as positive elements) are negotiated and not negated. 
This demonstrates, as fellow contributor Valerie Amiraux argues, that there is the possibility within Islam to express different religious beliefs. Jorgen Neilson notes in his chapter that many networks (e.g., the Indian Deobandis, the Brelwis, or the Tabligh-i-Jama'at) have gained a space and an influence in Europe that they cannot achieve in their home countries.

Many authors problematize singular conceptions of Islam. Unfortunately, quite often Muslim is taken for granted and regarded as self-evident and self-explanatory. Mandaville defines Muslims as "those who consider Islam and its regular practice to be a primary (although, as we will see, not necessarily as an exclusive one) component of self-identity" (p. 130), and considers those who fall outside this definition to be ethnic, non-universalistic, and cultural Muslims. Ironically, this definition looks similar to that of fundamentalists, who believe that religious identity is the Muslims' primary essence, despite the fact that one of the book's main aims is to demonstrate that European Islam is tolerant and pluralistic.

In making distinctions between religion, culture, and society, Stefano Allievi emphasizes similarities and minimizes differences and conflicts in the construction of a pan-Islamic global and deterritorialized ummah. In examining the tensions between the universal and the particular conceptions of Islam and Islamic identification, Steven Vertovec, in particular, focuses on the contemporary emergence of disaporic realities as "new processes of localization" (p. 318) and the existence of specific national forms of religion alongside universalist claims.

Strong conflicts exist in negotiating the complicated boundaries of religion, culture, and society. Galina Iemelanova clearly shows that the concept of orthodoxy and legitimacy varies according to historical and political situations. In the Russian autonomous republic of Dagestan, for example, the legitimate version of Islam is the Islam of tariqas, as opposed to Wahhabism, which is not automatically considered an "orthodox" current.

As part of this new cultural dynamic, Le Vine notes that Euro-Islam demonstrates a critical attitude, one characterized by the desire to reject dogmatism. Some Muslim intellectuals encourage people to read and interpret religious texts in a personal way and to advocate the development of new elaborations of figh in response to the multicultural context of European society. Unfortunately, the book does not explain in detail the sociocultural effects of these new discursive encounters, except Strassburger's analysis of Germany's Turkish community. There, a new conception of marriage - now more an individual than a family choice, 
and with more independence from the traditional framework of the husband's family - has been developed.

In attempting to understand the new discursive spaces emerging in Muslim Europe, Armando Salvatore and Shirin Amir-Moazami write that the Muslim potential of transformation stems from an impulse toward self-reform and a capacity to challenge dominant European notions of citizenship without any external impositions of secularism. The authors cite the wearing of hijab as a means to maintain modesty and, at the same time, to show how tradition can produce counter-discourses. For example, they use examples of the Prophet's life to support their claim that men should help their wives with domestic responsibilities. In doing so, the authors argue that Muslim women are affirming the right to be involved publicly in building a new social order.

In the case of European Sufi orders, Le Pape's chapter describes the influence René Guenon, a French mystic (1886-1951) who converted to Islam in 1912. Le Pape notes that when European Sufis go to the other side of the Mediterranean, they inevitably bring along a European hybrid of Sufism, comprised of Guenon's thought and their own interpretation of such Sufi thinkers as al-Ghazzali or Ibn `Arabi.

Other authors explore communication strategies and networks by analyzing the emergence of a Euro-Muslim public sphere. The role of public figures, intellectuals, or simply individuals that declare their own thought in public are of paramount importance for the visibility of Muslim communities in national European and transnational spaces. Anke Bentzin analyzes religious programs broadcast on the Berlin Open Channel, which allows Berlin Muslims to claim visibility in both Germany and in Muslim countries. The programs give first-hand information about Islam to a nonMuslim audience and examines topics of interest to Muslims living in Germany and abroad.

According to Le Vine, Euro-Muslims, like Arab Muslims, confront globalization by developing their own view of this process. He argues that while criticizing American hegemony, Muslims look for their own way to profit from globalization by enriching local cultures with universal values, as well as creating alternative modernities and an alternative to conservative Islam. Some authors also explored related issues of identity maintenance in transnational contexts. For example, Gaby Strassburger examines Turkish transnational marriages and reveals that German Turks still remain a closed group that does not mix with people of Moroccan origin living in Germany. 
In the region's vast geopolitical context, Yitzhak Shichor examines the case of the Uygurs, a Muslim minority living in the Chinese province of Xinjiang (Eastern Turkestan). The Uygurs secured their independence from China in 1933, but were invaded again in 1949. Expatriating in Europe and escaping from Chinese control and persecution, their cry for independence was heard globally through computer-mediated communication, websites, and forums. Thus, they gained international attention and concern. Here, Shikor tries to demonstrate that such globalization processes as transnational communication networks can keep ethnic identities and struggles alive through building transnational solidarities and alliances.

While this book deals with Muslim religious networks in the European public sphere, it does not detail all of these systems. Examples of new trends (claimed in some chapters) regarding the forms of interpretation, feedback, exchange, and hybridization between European Islam and other Muslim countries would have been helpful. Notwithstanding these problems, the book is both a good exploration of the pluralistic dynamics of European Islam and the broader ummah, and of the new efforts of interpretation that are adapting prevailing traditions to the European Muslim diaspora.

Barbara Caputo

Post-doctoral researcher and teacher, Dipartimento di Epistemologia

Università di Milano Bicocca, Milan, Italy 